\title{
BMJ Global Health Mapping global policy discourse on antimicrobial resistance
}

\author{
Didier Wernli, ${ }^{1}$ Peter S Jørgensen, ${ }^{2,3}$ Chantal M Morel, ${ }^{4,5}$ Scott Carroll, ${ }^{6,7}$ \\ Stephan Harbarth, ${ }^{4,8}$ Nicolas Levrat, ${ }^{1,9}$ Didier Pittet ${ }^{4,8}$
}

To cite: Wernli D, Jørgensen PS Morel CM, et al. Mapping global policy discourse on antimicrobia resistance. BMJ Glob Health 2017;2:e000378. doi:10.1136/ bmjgh-2017-000378

Received 21 April 2017 Revised 12 June 2017 Accepted 17 June 2017

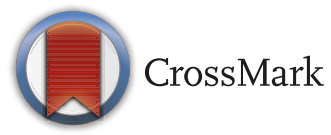

${ }^{1}$ Global Studies Institute,University of Geneva, Geneva, Switzerland ${ }^{2}$ Global Economic Dynamics and the Biosphere,Royal Swedish Academy of Sciences, Stockholm, Sweden

${ }^{3}$ Stockholm Resilience Centre,Stockholm University, Stockholm, Sweden

${ }^{4}$ Infection Control

Programme,University of

Geneva Hospitals and Faculty of Medicine, Geneva, Switzerland ${ }^{5}$ London School of Economics, London, UK

${ }^{6}$ Department of Entomology and Nematology, University of California, Davis, USA

${ }^{7}$ Institute for Contemporary

Evolution, Davis, USA

${ }^{8}$ WHO Collaborating Centre on Patient Safety,University of Geneva Hospitals and Faculty of Medicine, Geneva, Switzerland ${ }^{9}$ Faculty of Law,University of Geneva, Geneva, Switzerland

Correspondence to

Dr Didier Wernli; didier.wernli@ unige.ch

\section{ABSTRACT}

The rising importance of antimicrobial resistance (AMR) to the global health agenda is associated with a growing number of parties voicing their concern about the issue. With more recommendations and policies appearing, understanding the policy process requires making sense of the views, values, interests and goals of each participant. Policy frame analysis provides a method to understand both the scientific view and the actions advocated by global health actors to tackle AMR. Here we review and refine policy frame analyses of AMR using a deductive approach. Among several policy frames previously defined in the field of global health, we identify 'AMR as healthcare', 'AMR as development', 'AMR as innovation' and 'AMR as security' as frequent frames used in dealing with AMR. In addition, we found that 'AMR as One Health' constitutes a recent framing of the topic that seeks to provide an integrated understanding between human and animal health. Each frame originates in distinct scientific fields, conceptualises the main causes of AMR and prioritises different interventions and measurements. Better understanding and integration of these frames into an overarching social and ecological framework will support policy progress in tackling AMR.

\section{BACKGROUND}

Over the last threeyears, antimicrobial resistance (AMR) has attracted unprecedented attention at the highest political levels, as evidenced by the 2015G7 meetings in Germany and Japan, several country-level initiatives, ${ }^{1}$ resolutions and policy instruments produced by international organisations such as WHO, the Organization for Animal Health (OIE), the Food and Agriculture Organization of the United Nations (FAO) $)^{2-4}$ and the September 2016 United Nations high-level meeting on AMR. ${ }^{5}$ This attention reflects the progression of the problem as rising AMR is ubiquitous, concerns virtually all pathogens relevant to human health and, in certain cases, is reaching levels where few options, if any, are left to treat infected patients. While AMR has been studied and addressed technically for decades, this attention also indicates that AMR has transformed into a global governance priority, which requires international

\section{Key questions}

What is already known about this topic?

- There is a growing interest in addressing antimicrobial resistance (AMR) at the local, national and international levels. AMR also requires a coordinated response across sectors including human and animal health, development and trade. Many actors are voicing their concern about AMR and recommending a wide array of actions to tackle the problem but we have limited understanding of the main policy discourse to address AMR.

What are the new findings?

- We identified 'AMR as healthcare', 'AMR as development', 'AMR as innovation', 'AMR as security' and 'AMR as One Health' as frequent ways of framing AMR. Each of these frames has its own scientific origin, conceptualisation of the problem and priority. None of these frames is sufficiently integrative to manage alone the complexity of the scientific challenge, which is multisectoral.

\section{Recommendations for policy}

- Providing a better understanding of the competing discourses that prevail regarding AMR can support those seeking to draw attention on the problem to tailor their message to different constituencies. Better understanding and integration of AMR policy frames into an overarching social and ecological framework can help identify the main tensions and synergies between priorities and support policy progress in tackling AMR.

cooperation. The global response to AMR also rests on collaboration between sectors including human and animal health, the environment, trade, intellectual property and innovation. Achieving collaborative action across sectors that have traditionally fallen within separate policy spheres is a difficult challenge. This challenge is even harder as the rise of AMR on the global health agenda means that typical political variables such as interests, power and narratives have become prominent components of the policy process. Today a growing number of actors are voicing their concern about the issue including 
national governments, international organisations, public-private partnerships, think tanks, academia, the pharmaceutical industry and civil society. ${ }^{6}$ These global health actors present AMR in different ways, which imply distinct values and solutions. Within what resembles a policy cacophony, it has become difficult to identify where ideas come from and what they entail and prioritise. ${ }^{7} \mathrm{We}$ seek to disentangle this complexity by identifying how global health actors frame the issue of AMR. The analysis provides a framework to understand not only the diversity of opinions and interests, but also their potential to converge or to compete in a crowded global health arena. We suggest that broader discussion of AMR within its interlinked ecological and social dimensions can improve how we deal with AMR.

\section{METHODS}

In the social world, participants often have competing perspectives about the origins, importance and unfolding of phenomena. Taken together these elements form 'policy frames'. As key elements of the policy process, they not only provide an understanding of the problem (cognitive dimension) but they are also underpinned with values and by what ought to be done (normative dimension). ${ }^{8}$ Policy frames can be understood in the context of the relation between knowledge, policy and power. Timely and adequate framing can attract attention at the policy and political levels. ${ }^{9}$ With a growing literature dedicated to policy frames in global health, ${ }^{8-12}$ recent analysis suggests that both competition and convergence can arise from differential framing of a policy issue. ${ }^{11}$ In the early phase of policy attention, competition between frames is expected, especially when they originate in different sectors. ${ }^{13}$ Indeed, differential framing constitutes the basis of the policy debate. However, prolonged competition can be a symptom of diverging interests or irreconcilable values, which can in turn hamper policy coherence or result in gridlock. By contrast, we suggest that innovative framing based on an interdisciplinary approach can support policymaking by internalising tensions and providing an ideational space for negotiating and addressing them.

To identify global health frames relevant to AMR, we used a deductive approach starting from frames developed in previous works in global health. Frequent framing of global health issues includes evidence-based medicine, ${ }^{14}$ securitisation of global health issues, ${ }^{1016} 17$ economics and innovation, ${ }^{16} 18$ and development, equity and human rights. ${ }^{8} 1619$ The analysis was supported by policy documents on AMR collected from global health actors (eg, governments, international organisations, non-governmental organisations (NGOs)). By policy document, we refer to non-academic papers that articulate recommendations for interventions to be implemented. A pool of documents was assembled through complementary strategies. The first was based on searching the website of key actors in dealing with AMR (a useful list of

\begin{tabular}{|c|c|}
\hline Variables & Description \\
\hline Worldview & $\begin{array}{l}\text { How the problem is considered including } \\
\text { the underpinning (scientific) assumptions }\end{array}$ \\
\hline Origin/history & How the frame developed \\
\hline Actors & $\begin{array}{l}\text { What are the main actors responsible } \\
\text { for tackling the problem of antimicrobial } \\
\text { resistance }\end{array}$ \\
\hline Interventions & What kind of policies are advocated \\
\hline Measurements & How the problem is measured \\
\hline Use in policy & $\begin{array}{l}\text { How the policy frame has been used in } \\
\text { policy documents }\end{array}$ \\
\hline
\end{tabular}

actors on AMR was compiled by ReAct). ${ }^{6}$ In particular, key policy documents on AMR from international organisations including $\mathrm{WHO}$, OIE and FAO were collected in relation to a parallel ongoing research project on the global governance of AMR. Second, we also collected national strategies on AMR based on the information provided by the WHO website. Third, further documents were retrieved by scanning the reference lists of the documents initially identified. In total, $>200$ documents were assigned to relevant global health frames. In addition to finding frequent use of these frames-healthcare, security, development and innovation-we found that a new frame that we labelled 'One Health' was relevant to the AMR policy discourse. To structure our critical discourse analysis of the frames identified above, ${ }^{20}{ }^{21}$ we decomposed each of them into five constituents, which we defined as worldview, origin, the main actors involved, interventions and measurements (a short description of these variables is provided in table 1). We selected these variables to not only capture how different actors conceptualise the problem (worldview) and rely on scientific enquiry (origin), but also to understand what kind of interventions and measurement they prioritise to achieve their goals. As the WHO Global Action Plan (GAP) adopted in 2015 is the main policy instrument at the global level, we provide examples of current use of these frames in this document.

\section{RESULTS}

\section{Frame 1: AMR as a healthcare issue} Worldview

The starting point of the healthcare policy perspective is that AMR is a biomedical problem that manifests itself primarily in healthcare settings, while clinicians deal with infectious diseases such as common respiratory or urinary tract infections or specific diseases (eg, tuberculosis, HIV, malaria). The healthcare AMR policy frame rests on a disease-based conceptualisation of global health and derives from several scientific theories (including evolution, germ, genetics) that are foundational to the biomedical paradigm. ${ }^{22}$ 


\section{Origin}

This policy frame has a long history and has served as the nearly unique AMR discourse for many decades. Since the widespread introduction of antibiotics in medical practice in the $1950 \mathrm{~s}$, it was quickly recognised by the medical community that bacteria have the ability to become resistant to antibiotics. ${ }^{23}$ However, AMR was not considered a significant problem within the prevailing context of that time, when new drugs were still being rapidly discovered and infectious diseases were receding, particularly in high-income countries (HICs). In the 1980 s and increasingly onwards, AMR started to be perceived as a real problem in clinical practice with the emergence of many clinically significant resistant strains in common pathogens such as multiresistant Staphylococcus aureus, Streptococcus pneumoniae, Pseudomonas aeruginosa, Mycobacterium tuberculosis and Plasmodium falciparum.

\section{Actors}

Actors that have traditionally promoted a biomedical approach to AMR include medical societies such as the Infections Diseases Society of America in the USA or the European Society of Clinical Microbiology and Infectious Diseases in Europe. These societies release guidelines on how to tackle the problem. ${ }^{24}$ Reflecting the importance of the problem for the medical community, several scientific journals have been dedicated to AMR. These journals publish primarily fundamental and clinical research in biomedicine (eg, Journal of Antimicrobial Chemotherapy).

\section{Interventions}

The healthcare policy frame focuses on interventions within the health sector to reduce the burden of AMR through early diagnosis and adequate treatment, often referring to the rational or prudent use of medicine. While the healthcare policy frame primarily promotes individual curative and technical solutions to the problem of AMR, it has also come to emphasise infection prevention and control. More particularly antibiotic stewardship focuses on prescribing the right drug at the right dose and for the right duration to reduce the spread and emergence of new resistance and the burden of infection in the first place.

\section{Measurements}

Infections by pathogens that exhibit resistance affect health outcomes such as morbidity and mortality. They also overburden hospital capacities and increase the likelihood of treatment failure and the risks associated with other common treatments in medicine (eg, surgery, immunosuppression). ${ }^{25}{ }^{26}$ AMR as a healthcare issue is typically measured in terms of (1) proportion of resistant pathogens for a number of commonly used antibiotics, (2) adverse health outcome such as mortality, morbidity and (3) more recently in cost terms such as those associated with prolonged length of stay in hospital.

\section{Policy}

In many policy documents, the healthcare frame remains important or central. In the GAP, the healthcare frame is well represented by objective 4 about optimising the use of antimicrobial medicine in healthcare through stewardship and related programmes. ${ }^{2}$

\section{Frame 2: AMR as a development issue Worldview}

Despite the progress in controlling infectious diseases in the global North, the persistence of a high burden of infectious disease in low-and-middle-income countries (LMICs) associated with weak health systems has created the breeding ground for AMR to develop as a pressing issue. ${ }^{27} 28$ From the perspective of development, which is one of the main frames in the field of global health, AMR is closely linked to poverty, lack of sanitation and poor hygiene. Poor access to antimicrobials increases the burden of infectious diseases but is also associated with misuse of antibiotics. Causes of misuse range from lack of awareness, absence of regulations, and the consumption of counterfeit and substandard medicine that are typically sold at lower prices and without prescription. ${ }^{29}$ Recent literature has argued that 'Substandard, spurious, falsely labelled, falsified and counterfeit' medicine favours the emergence of AMR. ${ }^{30}$ The development frame of AMR is rooted in the normative standpoint that inequalities should be reduced and that all individuals have the right to health including access to essential medicine such as antimicrobials. ${ }^{31}$

\section{Origin}

Historically, the focus on AMR in LMICs has featured prominently in publications related to pathogens responsible for specific diseases resulting in high health burden including tuberculosis, ${ }^{32}$ malaria and HIV-AIDS, all of which have developed significant levels of resistance. Resistant tuberculosis reached high levels $>10$ years ago, giving rise to the practice of directly observed treatment, while the more recent emergence of artemisinin resistance in South-East Asia could prove to be a major blow in dealing with malaria. ${ }^{33}$ The lack of access to quality medicine was put on the international agenda by NGOs such as MSF, which played a leading role, in the early 2000s, of advocating better access to essential drugs against HIV-AIDS in LMICs. ${ }^{34}$ These contributed to change in global governance with the adoption of the DOHA declaration on the Trade-Related Aspects of Intellectual Property Rights Agreement and Public Health in 2001 and the creation of new organisations such as the Global Fund and the Drugs for Neglected Diseases initiative. As the main discourse on development has shifted towards 'sustainable development' at the end of the Millennium Development Goals, AMR has recently come to be presented as a sustainable development issue. ${ }^{35}$ Although AMR is not specifically mentioned in the sustainable development goals except in the introduction of the declaration, ${ }^{36}$ it is increasingly presented 
as the overexploitation of a common pool resource, ${ }^{37-40}$ which might prevent the achievement of several targets of the Sustainable Development Goals. ${ }^{35}$

\section{Actors}

Typical actors engaged in the development framing are LMICs and the governmental agencies in HICs that channel aid to LMICs. NGOs such as Doctors Without Borders and policy networks such as ReAct also play a role both in advocacy and implementation of best practice in LMICs. The Access to Medicine Index has focused on holding pharmaceutical companies accountable by assessing their policies regarding access to medicine. ${ }^{41}$

\section{Interventions}

The main intervention promoted through this frame is to provide greater access to quality medicine, an evermore pressing issue, as resistance to first-line drugs becomes widespread in many parts of the world.

\section{Measurements}

The problem of AMR as an access issue has given rise to a limited number of indicators as it remains difficult to measure the proportion of population that has access to necessary antimicrobials. Indirect indicators include the price of medicine or the access to specific drugs such as second-line treatment and other new technologies. Because of the challenge to measure access, global health actors such as Health Action International conduct in-depth evaluation of price and availability in some studies. A study conducted in 2013 in New Delhi found that reduced availability of essential antibiotics was concomitant to inappropriate pricing of newer drugs. ${ }^{42}$

\section{Policy}

In the GAP, the issue of access is integrated in objective five above innovation. The GAP underlines that 'the aim to preserve the ability to treat serious infections requires both equitable access to, and appropriate use of, existing and new antimicrobial medicines'.?

\section{Frame 3: AMR as an innovation issue Worldview}

As an issue of innovation, the main concern regarding AMR is that R\&D for new substances and, to a lesser extent, diagnostics has not kept up with the evolution of resistance. Because of AMR, antimicrobials become less efficient or even obsolete and new substances have to be developed continuously. According to the 'law' of supply and demand, in a free market, antimicrobials should be produced as needed by society. However, externalities in healthcare and in infectious disease treatments in particular (eg, surrounding resistance) make antibiotics a highly imperfect market. Further, the imperfect prediction of resistance to current, largely inexpensive, treatments and the resulting magnitude of future clinical need make future demand for antibiotics more uncertain than other therapeutic areas. Together these factors decrease the attractiveness of investing in antibiotic R\&D.

\section{Origin}

While the 1950s were the golden age of antibiotic discovery with many new classes found, the waning of R\&D started in the 1970s and accelerated from the 1980s. ${ }^{43}$ AMR first became a concern in some HICs in the $1990 \mathrm{~s}^{44}$ but the innovation policy frame clearly emerged around the year 2000 at a time when the acceptance of new substances by regulatory authorities declined. While new substances have been marketed in the last 10 years, few are based on new modes of action or cover the most urgent needs including Carbapenem-resistant Enterobacteriaceae. $^{45}$

\section{Actors}

As with most commodities, the leader in technological expertise to develop innovative antibiotics tends to lie in private industry. As such, countries that have a strong pharmaceutical sector, particularly in HICs, are likely to frame AMR as an innovation issue. The review on AMR in the UK is a good illustration of this. ${ }^{1}$

\section{Interventions}

The innovation policy frame seeks to address the fact that pharmaceutical companies are no longer interested in new antibiotic R\&D due to lower return on investment compared with other drugs and the risks associated with the development of truly novel products. ${ }^{46}$ The primary solutions to overcome the challenges of the market are targeted push-and-pull incentives as well as regulatory tools $^{47}$ that help increase the relative attractiveness of investment and bring back financial and human capital to this area of research.

\section{Measurements}

In terms of measuring AMR within this policy frame, indicators include the number of new antibiotics (based on new modes of action) on the market, the proportion of overall pharmaceutical R\&D investment that is dedicated to antibiotics, as well as the number and quality of push-and-pull mechanisms to incentivise companies to research and develop new antibiotics.

Policy

The innovation frame has featured prominently in many policy documents in recent years, including in objective five of the GAP which is to "develop the economic case for sustainable investment that takes account of the needs of all countries, and increase investment in new medicines, diagnostic tools, vaccines and other interventions'.

\section{Frame 4: AMR as a security issue Worldview}

While health security is 'essentially the protection from threats to health", ${ }^{48}$ two often contradictory views prevail. On the one hand, global health security rests on the idea of 'human security', which stresses the security of individual and expands the concept of security to the main vulnerabilities arising from globalisation. ${ }^{49}$ On the other hand, security inevitably refers to national security ${ }^{50}$ and 
global health security tends in practice to reflect the concerns of the global North vis-à-vis the international spread of diseases originating in the global South. ${ }^{50}$ Indeed a growing trend is to pinpoint areas where AMR is not controlled and thereby putting the global North in peril-as exemplified by the identification of NDM-1 as a new mechanism of resistance to carbapenems in India in $2011 .{ }^{51}$

\section{Origin}

Since the 1990s and even more after the 11 September 2001 events, security has become a common way to frame health issues stemming from emerging and re-emerging diseases. ${ }^{52}$ The securitisation of global health issues has attracted sustained attention in policy circles and in the scientific literature, especially from scholars of international relations. ${ }^{49} 5253$ The limit of the applicability of the security frame to AMR is that, in contrast to acute threats such as Ebola, AMR to date has not yet triggered any large-scale community-based outbreaks capable of disrupting health systems or economies. AMR is mostly a slow motion disaster. ${ }^{54}$ In that regard, the applicability of the International Health Regulations (IHR) to AMR, the global framework for global health security, remains elusive. ${ }^{55}$

\section{Actors}

In a security perspective, the main actors are nation states whose responsibilities are to maintain public health, which is one of the seminal functions of the state. Ministries of health are to collaborate with ministries of trade and foreign affairs to make sure that AMR does not disturb the highest-level political priorities such as trade and security. Actors that have endorsed a security view of AMR include mainly countries in the global North. The G7 recently qualified AMR as a security threat and the US Centers for Disease Control released the report entitled 'Antibiotic resistance threats in the United States' in 2013. ${ }^{56}$ AMR is also part of the Global Health Security agenda. ${ }^{57}$

\section{Interventions}

In terms of policy interventions, the global health security frame emphasises the need for improving global surveillance of AMR along with other threats to public health and for developing core national capacities to respond to AMR outbreaks before they spread across and between countries. Systematic surveillance appears as a prerequisite for containment of AMR at its source, although evidence to support this policy is challenged by the typically broad environmental dissemination of the genes observed once resistant pathogens are clinically detected. ${ }^{58}$

\section{Measurements}

The security frame is associated with measurements such as the epidemiology of resistance, mortality rate and the evaluation of the spread of resistance across countries often using techniques in molecular biology.

\section{Policy}

The AMR security frame emerged in policy documents in the 2000s. In 2005, the WHO secretariat prepared a report entitled 'Antimicrobial resistance: a threat to global health security ${ }^{59}$ WHO further included AMR as a security issue in the World Health Report 2007 considering that 'the continuing development of resistance to antimicrobial drugs represents a major factor in the emergence and re-emergence of infectious disease ${ }^{6}{ }^{60}$ The GAP refers to AMR as a threat to human health, although the issue of containment is not very developed. While reference to the IHR regarding the surveillance of AMR is made in the GAP, there is none regarding the control of AMR.

\section{Frame 5: AMR as a One Health issue Worldview}

One Health has been broadly defined as 'the collaborative effort of multiple disciplines-working locally, nationally, and globally - to attain optimal health for people, animals and our environment ${ }^{61}$ In practice, it has primarily been based on the idea that benefits will accrue in addressing health issues in an integrated way as human and animal health lie in the same paradigm. As AMR originates from the use of antibiotics in both human and animal health, the One Health frame matches the scientific challenges associated with it. The identification of MCR-1, a gene that confers resistance to colistin, seems a strong case for the existence of complex interconnections between animal and human health. Historically colistin has been widely used in animal health and not in human health $;{ }^{62}$ however, with growing resistance to treatment alternatives it has become a drug of last resort for humans in many settings. As massive amounts of antibiotics are used in agriculture, especially for non-therapeutic use, and because antibiotic resistance genes and antibiotic residue diffuse in the wider environment, ${ }^{63-65}$ the problem has recently come to be seen as a growing environmental problem that could ultimately have important repercussions for our ability to treat infections among humans.

\section{Origin}

While the thinking that underpins One Health is not new, the use of One Health as a policy frame is rather recent in global health. Originally linked to work in rural regions mainly in LMICs, ${ }^{66}$ the One Health frame has developed against the background of the rising number of zoonoses (eg, influenza, Creutzfeldt-Jakob disease) and been supported by improvements in understanding complex interactions in ecosystems. It has expanded quickly in recent years, especially surrounding AMR due to the common use of antibiotics in agriculture ${ }^{67}$ and the potential harm to human health. Indeed, AMR has recently been described as the quintessential One Health issue in the literature. ${ }^{68}$

\section{Actors}

There has been a wide endorsement of the One Health approach not only by the scientific community but also 
by international organisations and national governments. At the international level, it has proved a converging frame to promote collaboration between OIE, FAO and WHO. ${ }^{69}$

\section{Interventions}

The One Health concept underlines the complexity of the science behind AMR and demands further research on the links between the use of antibiotics in animal and human health. In terms of policy response, One Health underpins primarily better coordination and collaboration between human and animal health/agriculture. An example of a relevant intervention is the European Union (EU) ban on the use of antibiotics as growth promoters. ${ }^{70}$

\section{Measurements}

One of the main obstacles to the implementation of a One Health frame comes from the difficulty in identifying and operationalising appropriate indicators of success and failure. The broad scope of the One Health frame calls for instruments measuring AMR in a multidimensional, cross-sectoral fashion.

\section{Policy}

The One Health frame now features prominently as an overarching approach to containing AMR in plans such as the GAP and in the national strategy of several countries including Switzerland. ${ }^{71}$

\section{DISCUSSION}

Our analysis identified five dominant frames addressing AMR (summarised in table 2) across the published and unpublished literature. Given the predominantly deductive approach taken in this paper, we cannot exclude that other relevant AMR frames exist. In addition, as important parts of the policy debate take place outside of formal documents, it is possible that we missed some frames. Finally, there is some variation in how these frames are used in the literature, which our categorisation does not fully reflect. Despite these limitations, our findings have implications for both science and governance. First, based on our analysis of frames' worldview, it appears that the five frames above have largely been influenced by the structuring of knowledge into academic disciplines. ${ }^{72}$ While each frame provides a coherent understanding of the problem, none is sufficiently integrative to manage alone the complexity of the scientific challenge, which spans many academic disciplines. This underlines the importance of interdisciplinary research to underpin action regarding AMR. Second, recognising where ideas come from and what they imply contributes to understanding the policy process. As a multisectoral framework that seeks to trigger and sustain a society-wide effort, the GAP refers to some extent to all frames. Our findings provide then an approach to research how countries prioritise different aspects of the GAP as they are currently developing their own national action plan. Governments themselves may use these findings to understand the origins and implications of different frames and re-evaluate their approach to AMR. Third, the results corroborate the idea that global health governance is a contested scientific and political space where different actors pursue their own goals and seek to achieve and project power. ${ }^{73}$ AMR is no exception even though it was historically a highly technical and biomedical issue. The recent proliferation of actors involved in and initiatives dedicated to $\mathrm{AMR}^{6}$ demonstrates that, having gained traction on the global health agenda, the problem is increasingly politicised. This means that countries and other actors privilege frames and policies

Table 2 Summary of policy frames on antimicrobial resistance (AMR)

\begin{tabular}{|c|c|c|c|c|c|}
\hline & $\begin{array}{l}\text { AMR as healthcare } \\
\text { problem }\end{array}$ & $\begin{array}{l}\text { AMR as } \\
\text { development issue }\end{array}$ & $\begin{array}{l}\text { AMR as innovation } \\
\text { challenge }\end{array}$ & $\begin{array}{l}\text { AMR as security } \\
\text { issue }\end{array}$ & $\begin{array}{l}\text { AMR as One health } \\
\text { challenge }\end{array}$ \\
\hline Definition & $\begin{array}{l}\text { Health impact of } \\
\text { AMR on human } \\
\text { health }\end{array}$ & $\begin{array}{l}\text { AMR as an obstacle } \\
\text { to development }\end{array}$ & $\begin{array}{l}\text { Market failure and } \\
\text { lack of access to } \\
\text { antibiotics }\end{array}$ & $\begin{array}{l}\text { AMR as threat to the } \\
\text { stability of health } \\
\text { and social systems }\end{array}$ & $\begin{array}{l}\text { Health impact of } \\
\text { AMR on animal and } \\
\text { human health }\end{array}$ \\
\hline Metaphor & War on microbes & Health for all & Magic pills & Fear of the 'other' & $\begin{array}{l}\text { The environmental } \\
\text { link }\end{array}$ \\
\hline Goals & $\begin{array}{l}\text { Maximise the impact } \\
\text { for patients }\end{array}$ & $\begin{array}{l}\text { Guarantee access } \\
\text { to medicine as a } \\
\text { prerequisite for } \\
\text { development }\end{array}$ & $\begin{array}{l}\text { Provide new drugs } \\
\text { to responds to } \\
\text { growing demand } \\
\text { from consumers }\end{array}$ & $\begin{array}{l}\text { Protect against the } \\
\text { international spread } \\
\text { of disease }\end{array}$ & $\begin{array}{l}\text { Enhance human and } \\
\text { animal health }\end{array}$ \\
\hline Measurements & $\begin{array}{l}\text { Epidemiology of } \\
\text { AMR and health } \\
\text { impact }\end{array}$ & Access to medicine & $\begin{array}{l}\text { Economic } \\
\text { Investment in R\&D }\end{array}$ & $\begin{array}{l}\text { Escalating costs } \\
\text { and impact of AMR } \\
\text { on society }\end{array}$ & $\begin{array}{l}\text { Consequences of } \\
\text { AMR on animal and } \\
\text { human health }\end{array}$ \\
\hline $\begin{array}{l}\text { Typical actors } \\
\text { (non-exclusive) }\end{array}$ & $\begin{array}{l}\text { General public, } \\
\text { medical } \\
\text { professionals, health } \\
\text { systems }\end{array}$ & $\begin{array}{l}\text { NGOs, international } \\
\text { organisations, } \\
\text { LMICs }\end{array}$ & $\begin{array}{l}\text { Governments in } \\
\text { HICs }\end{array}$ & $\begin{array}{l}\text { Governments in } \\
\text { HICs }\end{array}$ & $\begin{array}{l}\text { Animal sector, } \\
\text { International } \\
\text { organisations, } \\
\text { governments }\end{array}$ \\
\hline
\end{tabular}

HIC, high-income countries; LMIC, low-and-middle-income countries; NGOs, non-governmental organisations. 
that further their own interest regarding both health and other agenda such as trade, security and development as illustrated by recent discussion at the World Health Assembly. ${ }^{74}$ As AMR intersects with the governance of areas such as food production, security, trade and innovation as summarised in table 3 , this can give rise to forum shopping which 'involves actors seeking to realise their policy objectives within preferred policy arenas on the basis of an arena's particular governing characteristics'. ${ }^{75}$

The intersectoral nature of AMR also generates tensions between policy priorities that are interdependent. First, the security frame tends to privilege the interest of HICs to protect themselves from global health threats coming from LMICs, ${ }^{76}$ but it is difficult to achieve security without development as both are ultimately linked. The creation of a conservation fund to help LMICs to address the problem could help to reconcile these two goals. ${ }^{77}$ Second, the development frame, which entails access to health technologies and is typically addressed in human rights arena ${ }^{78}$ conflicts with the innovation frame which is governed by the World Trade Organization (WTO) and the World Intellectual Property Organization (WIPO). The strong interest of HICs to protect their pharmaceutical sectors is illustrated by their pursuit of bilateral trade agreements, often labelled 'TRIPS+' (in reference to the Trade-Related Agreement on Intellectual Property administered by WTO), which have more stringent protection of intellectual property than WTO rules and seek to limit the use of flexibilities for the protection of public health. ${ }^{79}$ The option of delinking revenues from unit sales might reconcile the two sides of the problem by overcoming the dilemma between rewarding innovation and providing access. ${ }^{80}$ Finally, innovation makes no sense without (1) containment strategies such as stewardship and infection prevention and control in healthcare and (2) strategies on the conservation of antimicrobials effectiveness across sectors through the healthcare and the more integrative One Health frames. However, tensions exist between the human and animal health sectors. While the human health sector has generally advocated a ban of the use of antimicrobials as growth promoter in animal husbandry as the EU did in 2006, ${ }^{81}$ the issue is less prominent in animal health constituencies such as OIE, as illustrated by the absence of mention of growth promotion in the 2016 'OIE strategy on AMR and the prudent use of antimicrobials'. ${ }^{3}$ In many countries, powerful agriculture lobbies are opposed to phasing out growth promotion as commercial interest are at stake.

Overall, these examples suggest that an understanding of the interdependencies between policy priorities and their related frames is essential to strike a balance between competing views of the problem and support decisive policy innovation in dealing with AMR. An integrative scientific framework cannot by itself reconcile conflicting values and interests but it can certainly illuminate, clarify and help to explain the intrinsic tensions in the debate, and thereby facilitate discussion and negotiation in the global health arena. In other words, the role

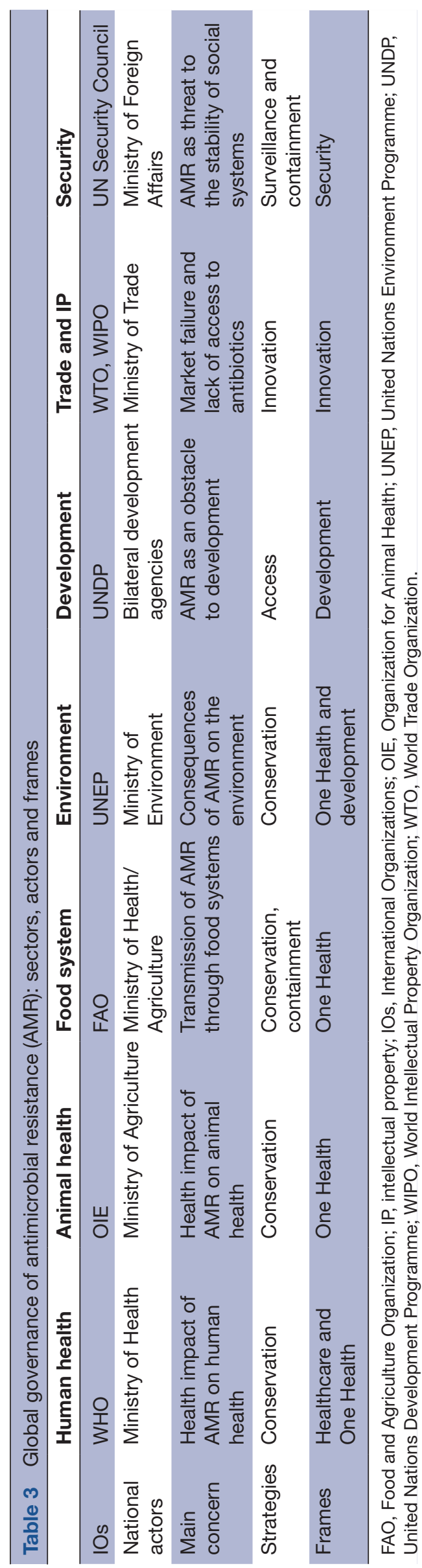


of science is to provide the appropriate stage on which negotiation can occur. Intersectoral action is by its nature challenging but the HIV-AIDS epidemic proved that action across sectors is possible when (1) political will and public pressure are present, (2) adequate convening fora are found and (3) frames can be aligned to achieve a common understanding of the problem. ${ }^{11}$ While our analysis demonstrates that each frame shed light on an important aspect of AMR, One Health already provides a converging way to conceptualise and address AMR. In order to support policies that address the problem comprehensively, what is now needed is a social-ecological framework to consider the preservation of antimicrobials' effectiveness as a planetary health issue, ${ }^{82}$ where the global microbiome is seen as a non-renewable resource that is essential for both human health and the health of the planet. ${ }^{40}$ By assessing both the social and the ecological dimensions of the problem from a complex adaptive systems perspective, such holistic 'planetary health' framing can not only provide an umbrella for future negotiations on the topic but also further support the international and interorganisational cooperation that has become so crucial to addressing AMR.

Contributors DW designed the study, analysed the data and drafted the paper; PSJ, CMM, SC, SH, NL and DP provided text and edited the manuscript. DW produced the tables.

Competing interests None declared.

Provenance and peer review Not commissioned; externally peer reviewed.

Data sharing statement № additional data are available.

Open Access This is an Open Access article distributed in accordance with the Creative Commons Attribution Non Commercial (CC BY-NC 4.0) license, which permits others to distribute, remix, adapt, build upon this work non-commercially, and license their derivative works on different terms, provided the original work is properly cited and the use is non-commercial. See: http://creativecommons.org/ licenses/by-nc/4.0/

(C) Article author(s) (or their employer(s) unless otherwise stated in the text of the article) 2017. All rights reserved. No commercial use is permitted unless otherwise expressly granted.

\section{REFERENCES}

1. The review on antimicrobial resistance. Tackling drug-resistant infections globally - Final Report and Recommendations 2016 https://amr-review.org/sites/default/files/160518_Final\%20paper_ with\%20cover.pdf (accessed 12 June 2017).

2. World Health Organization. Global Action Plan on Antimicrobial Resistance. Geneva: World Health Organization 2015 http://www. who.int/antimicrobial-resistance/publications/global-action-plan/en/ (accessed 18 March 2017).

3. OIE. The OIE Strategy on Antimicrobial Resistance and the prudent use of antimicrobials. Paris: OIE 2016 http://www.oie.int/ fileadmin/Home/eng/Media_Center/docs/pdf/PortailAMR/EN_OIEAMRstrategy.pdf (accessed 18 March 2017).

4. FAO. The FAO Action Plan on antimicrobial resistance 2016-2020. Roma: FAO 2016 http://www.fao.org/3/a-i5996e.pdf (accessed 18 March 2017).

5. United Nations. Political declaration of the high-level meeting of the General Assembly on antimicrobial resistance. New York: United Nations 2016 http://www.un.org/pga/71/wp-content/uploads/ sites/40/2016/09/DGACM_GAEAD_ESCAB-AMR-Draft-PoliticalDeclaration-1616108E.pdf (accessed 18 October 2016).

6. ReAct. AMR Stakeholder mapping. Uppsala:. 2016 https://www. reactgroup.org/uploads/Stakeholder\%20Analysis_ReActForWHO. pdf (accessed 18 March 2017).
7. Lang T, Rayner G. Overcoming policy cacophony on obesity: an ecological public health framework for policymakers. Obes Rev 2007;8 Suppl 1(Suppl 1):165-81.

8. Mclnnes C, Lee K. Global health and international relations. Cambridge: Polity, 2012.

9. Shiffman J. A social explanation for the rise and fall of global health issues. Bull World Health Organ 2009;87:608-13.

10. Stuckler D, McKee M. Five metaphors about global-health policy. Lancet 2008;372:95-7.

11. Mclnnes C, Roemer-Mahler A. Competition and Cooperation in Global Health Governance: the Impact of Multiple Framings. In: Freeman M, Hawkes S, Bennett B, eds. Law and Global Health: current Legal Issues. 16, 2014. Volume Oxford Scholarship Online.

12. Gopinathan U, Watts N, Hougendobler D, et al. Conceptual and institutional gaps: understanding how the WHO can become a more effective cross-sectoral collaborator. Global Health 2015;11:46.

13. Mason Meier B. An Agenda for Normative Policy Analysis in the Study of Global Health Governance. In: Freeman M, Hawkes S, Bennett B, eds. Law and Global Health: current Legal Issues. 16, 2014. Volume Oxford Scholarship Online.

14. Mclnnes C, Kamradt-Scott A, Lee K, et al. Framing global health: the governance challenge. Glob Public Health 2012;7 Suppl 2(Suppl 2):S83-S94.

15. Kamradt-Scott A. Evidence-based medicine and the governance of pandemic influenza. Glob Public Health 2012;7 Suppl 2(Suppl 2):S111-S126

16. Labonté R, Gagnon ML. Framing health and foreign policy: lessons for global health diplomacy. Global Health 2010;6:14.

17. Kamradt-Scott A, Mclnnes C. The securitisation of pandemic influenza: framing, security and public policy. Glob Public Health 2012;7 Suppl 2(Suppl 2):S95-S110.

18. Labonté R. Global health in public policy: finding the right frame? Crit Public Health 2008;18:467-82.

19. Reubi D. Making a human right to tobacco control: expert and advocacy networks, framing and the right to health. Glob Public Health 2012;7 Suppl 2(Suppl 2):S176-S190.

20. van Dijk TA. Principles of critical discourse analysis. Discourse \& Society 1993;4:249-83.

21. Wodak R, Meyer M. Methods for critical discourse analysis. 2nd ed: Thousand Oaks: Sage, 2009.

22. Clark J. Medicalization of global health 1: has the global health agenda become too medicalized? Glob Health Action 2014;7:23998.

23. Podolsky SH. The antibiotic era: reform, resistance, and the pursuit of a rational therapeutics. Baltimore: Johns Hopkins University Press, 2015.

24. Barlam TF, Cosgrove SE, Abbo LM, et al. Implementing an antibiotic stewardship program: guidelines by the infectious diseases Society of America and the Society for Healthcare Epidemiology of America. Clin Infect Dis 2016:62:e51-e77.

25. Cosgrove SE. The relationship between antimicrobial resistance and patient outcomes: mortality, length of hospital stay, and health care costs. Clin Infect Dis 2006;42 Suppl 2(Suppl 2):S82-S89.

26. Cosgrove SE, Sakoulas G, Perencevich EN, et al. Comparison of mortality associated with methicillin-resistant and methicillinsusceptible Staphylococcus aureus bacteremia: a meta-analysis. Clin Infect Dis 2003;36:53-9.

27. Okeke IN, Laxminarayan $\mathrm{R}$, Bhutta ZA, et al. Antimicrobial resistance in developing countries. part I: recent trends and current status. Lancet Infect Dis 2005;5:481-93.

28. Okeke IN, Klugman KP, Bhutta ZA, et al. Antimicrobial resistance in developing countries. Part II: strategies for containment. Lancet Infect Dis 2005;5:568-80.

29. Mendelson M, Røttingen JA, Gopinathan U, et al. Maximising access to achieve appropriate human antimicrobial use in low-income and middle-income countries. Lancet 2016;387:188-98.

30. Kelesidis T, Kelesidis I, Rafailidis PI, et al. Counterfeit or substandard antimicrobial drugs: a review of the scientific evidence. J Antimicrob Chemother 2007;60:214-36.

31. Laxminarayan R, Matsoso P, Pant S, et al. Access to effective antimicrobials: a worldwide challenge. Lancet 2016;387:168-75.

32. World Health Organization. Anti-tuberculosis drug resistance in the world: the WHO/IUATLD Global Project on Anti-tuberculosis Drug Resistance Surveillance 1994 -. Geneva: WHO, 19971997.

33. Ashley EA, Dhorda M, Fairhurst RM, et al. Spread of artemisinin resistance in plasmodium falciparum malaria. $N$ Engl $\mathrm{J}$ Med 2014:371:411-23.

34. Brandt AM. How AIDS invented global health. N Engl J Med 2013;368:2149-52.

35. Jasovský D, Littmann J, Zorzet A, et al. Antimicrobial resistance-a threat to the world's sustainable development. Ups J Med Sci 2016;121:159-64. 
36. United Nations General Assembly. Transforming our world: the 2030 agenda for sustainable development. New York: United Nations 2015 http://www.un.org/ga/search/view_doc.asp?symbol=A/RES/70/1\& Lang $=E$ (accessed 18 March 2017).

37. Hollis A, Maybarduk P. Antibiotic resistance is a tragedy of the Commons that necessitates global cooperation. J Law Med Ethics 2015;43 Suppl 3:33-7.

38. Okeke I. The tragedy of antimicrobial resistance: achieving a recognition of necessity. Current science 2009;97:1564.

39. Laxminarayan R. Antibiotic effectiveness: balancing conservation against innovation. Science 2014;345:1299-301.

40. Jørgensen PS, Wernli D, Carroll SP, et al. Use antimicrobials wisely. Nature 2016;537:159-61.

41. Access to Medicine Foundation. Access to Medicine Index, 2016.

42. Kotwani A, Holloway K. Access to antibiotics in New Delhi, India: implications for antibiotic policy. J Pharm Policy Pract 2013;6:6.

43. Aminov RI. A brief history of the antibiotic era: lessons learned and challenges for the future. Front Microbiol 2010;1:134.

44. Podolsky SH, Bud R, Gradmann C, et al. History teaches Us that confronting antibiotic resistance requires Stronger Global Collective Action. J Law Med Ethics 2015;43 Suppl 3:27-32.

45. Bettiol E, Harbarth S. Development of new antibiotics: taking off finally? Swiss Med Wkly 2015;145:w14167.

46. Cooper MA, Shlaes D. Fix the antibiotics pipeline. Nature 2011;472:32

47. Renwick MJ, Brogan DM, Mossialos E. A systematic review and critical assessment of incentive strategies for discovery and development of novel antibiotics. J Antibiot 2016;69.

48. Heymann DL, Chen L, Takemi K, et al. Global health security: the wider lessons from the west african ebola virus disease epidemic. Lancet 2015;385:1884-901.

49. Rushton S. Global Health Security: security for whom? security from what? Polit Stud 2011;59:779-96.

50. Flahault A, Wernli D, Zylberman P, et al. From global health security to global health solidarity, security and sustainability. Bull World Health Organ 2016;94:863.

51. Kumarasamy KK, Toleman MA, Walsh TR, et al. Emergence of a new antibiotic resistance mechanism in India, Pakistan, and the UK: a molecular, biological, and epidemiological study. Lancet Infect Dis 2010;10:597-602

52. Davies SE. Securitizing infectious disease. International Affairs 2008;84:295-313

53. Aldis W. Health security as a public health concept: a critical analysis. Health Policy Plan 2008;23:369-75.

54. Chan M. Address to the Sixty-ninth World Health Assembly. Geneva: World Health Organization, 2016. http://www.who.int/dg/speeches/ 2016/wha-69/en/. (accessed 4 April 2017).

55. Wernli D, Haustein T, Conly J, et al. A call for action: the application of the International Health Regulations to the global threat of antimicrobial resistance. PLoS Med 2011;8:e1001022.

56. Centers for Disease Control and Prevention. Antibiotic resistance threats in the United States. 2013: Centres for Disease Control and Prevention, US Department of Health and Human Services 2013

57. Global Health Security Agenda. Antimicrobial Resistance Action Package. non dated https://www.ghsagenda.org/packages/p1antimicrobial-resistance (accessed 18 March 2017).

58. Berglund B. Environmental dissemination of antibiotic resistance genes and correlation to anthropogenic contamination with antibiotics. Infect Ecol Epidemiol 2015;5:28564.

59. World Health Organization. Antimicrobial resistance: a threat to global health security. rational use of medicines by prescribers and patients. Geneva: World Health Organization, 2005.

60. World Health Organization. The world health report 2007: a safer future. global public health security in the 21st century. Geneva: World Health Organization 2007.

61. American Veterinary Medical Association. One health: a new professional imperative. One Health Initiative Task Force Final Report. 2008 https://www.avma.org/KB/Resources/Reports/ Documents/onehealth final.pdf (accessed 3 June 2017).

62. Liu YY, Wang Y, Walsh TR, et al. Emergence of plasmid-mediated colistin resistance mechanism MCR-1 in animals and human beings in China: a microbiological and molecular biological study. Lancet Infect Dis 2016;16.
63. Glad T, Bernhardsen P, Nielsen KM, et al. Bacterial diversity in faeces from polar bear (Ursus maritimus) in Arctic Svalbard. BMC Microbiol 2010;10:10

64. Berendonk TU, Manaia CM, Merlin C, et al. Tackling antibiotic resistance: the environmental framework. Nat Rev Microbiol 2015;13:310-7.

65. Martínez JL. Antibiotics and antibiotic resistance genes in natural environments. Science 2008;321:365-7.

66. Zinsstag J, Schelling E, Waltner-Toews D, et al. From "one medicine" to "one health" and systemic approaches to health and well-being. Prev Vet Med 2011;101:148-56.

67. Van Boeckel TP, Brower C, Gilbert M, et al. Global trends in antimicrobial use in food animals. Proc Natl Acad Sci U S A 2015;112:5649-54.

68. Robinson TP, Bu DP, Carrique-Mas J, et al. Antibiotic resistance is the quintessential one Health issue. Trans $R$ Soc Trop Med Hyg 2016:110:377-80.

69. World Health Organization, Food and Agriculture Organization of the United Nations, World Organisation for Animal Health. The FAO-OIEWHO collaboration. sharing responsibilities and coordinating global activities to address health risks at the animal-human-ecosystems interfaces. A tripartite concept note 2010 http://www.who.int/ foodsafety/zoonoses/final_concept_note_Hanoi.pdf?ua=1 (accessed 18 March 2017).

70. Castanon Jl. History of the use of antibiotic as growth promoters in european poultry feeds. Poult Sci 2007;86:2466-71.

71. The Federal Council. Strategy on Antibiotic Resistance Switzerland, 2015. https://www.bundespublikationen.admin.ch/cshop_mimes bbl/8C/8CDCD4590EE41EE6A9FA4BAB41DE6BB3.pdf. (accessed 18 March 2017).

72. Wernli D, Darbellay F. Interdisciplinarity and the 21st century University. Brussels: League of European Research Universities, 2016.

73. Kickbusch I. Politics or technocracy - What next for Global Health? comment on "Navigating Between Stealth Advocacy and Unconscious Dogmatism: The Challenge of Researching the Norms, Politics and Power of Global Health". Int J Health Policy Manag 2015;5:201-4.

74. Saez C. World Health Assembly adopts Resolution to fight Sepsis; Antimicrobial Resistance Major threat. Intellectual Property Watch 2017 https://www.ip-watch.org/2017/05/26/world-health-assemblyadopts-resolution-fight-sepsis-antimicrobial-resistance-major-threat/ (accessed 3 June 2017).

75. Murphy H, Kellow A. Forum Shopping in Global Governance: understanding States, Business and NGOs in multiple arenas. Glob Policy 2013;4:139-49.

76. Hoffman SJ, Outterson K. INTRODUCTION: what will it take to address the global threat of Antibiotic Resistance? J Law Med Ethics 2015;43 Suppl 3:6-11.

77. Mendelson M, Dar OA, Hoffman SJ, et al. A global antimicrobial Conservation Fund for low- and Middle-Income Countries. Int $J$ Infect Dis 2016;51:70-2.

78. Human Right Council. Access to medicines in the context of the right of everyone to the enjoyment of the highest attainable standard of physical and mental health. Geneva: Human Right Council, 2016.

79. Abbott $\mathrm{F}$, . et a/Trade in medicines. In: Smith R, Blouin C, Mirza $\mathrm{Z}$, Drager N, Beyer $\mathrm{P}$, . eds. Trade and health: building a national strategy: world Health Organization, 2015.

80. Outterson K, Gopinathan U, Clift C, et al. Delinking Investment in Antibiotic Research and Development from sales revenues: the challenges of transforming a Promising Idea into reality. PLoS Med 2016;13:e1002043.

81. Commission of the European Communities. Ban on antibiotics as growth promoters in animal feed enters into effect (IP/05/1687) 2005.http://europa.eu/rapid/pressReleasesAction.do?reference= IP/05/1687\&type=HTML\&aged=0\&language $=E N \&$ guilanguage $=e n$ (accessed 20 November 2010).

82. Whitmee S, Haines A, Beyrer C, et al. Safeguarding human health in the Anthropocene epoch: report of the Rockefeller Foundation-Lancet Commission on planetary health. Lancet 2015;386:1973-2028. 